\title{
PENERAPAN KAPITALISASI SEWA OPERASI TERHADAP LAPORAN POSISI KEUANGAN DAN RASIO KEUANGAN PADA PERUSAHAAN DI INDONESIA
}

\author{
Ayunita Ajengtiyas Saputri Mashuri ${ }^{1)}$ Ratna Hindria Dyah Pita Sari ${ }^{2)}$ \\ ${ }^{1}$ Fakultas Ekonomi dan Bisnis, UPN Veteran Jakarta \\ email: ayunita.ajeng@upnvj.ac.id \\ ${ }^{2}$ Fakultas Ekonomi dan Bisnis, UPN Veteran Jakarta \\ email: ratnahindria@upnvj.ac.id
}

\begin{abstract}
The purpose of this study is to analyze the impact of capitalization on operating leases based on PSAK 73 which is applicable in the preparation of financial reports related to lease activities. The impact of the convergence of PSAK 73 application of IFRS 16 introduces a single accounting model that applies to the lessee party, while for the lessor there is no difference with the previous standard. The type of research is quantitative research with the data used is secondary data by utilizing the data available in the annual reports and financial reports of companies listed on the Indonesia Stock Exchange, the period 2018-2019. Secondary data is taken by pulling company data that reveals the value of the future minimum lease payments regarding the operating lease in the company's financial statements. The research sample used in this study is a company listed on the Indonsia Stock Exchange in the 2018-2019 period. Data analysis methods include descriptive statistical testing and Paired T-Test and Anova test using the Minitab 16 statistical application software. The results of this study indicate that operating lease capitalization has a significant effect on unrecorded lease liability, unrecorded lease assets, equity, and financial ratios. Also, empirical evidence shows that there are tax savings from capitalizing operating leases
\end{abstract}

Keywords: PSAK 73, Operating Lease, Constructive Capitalization, Financial Statements

\begin{abstract}
ABSTRAK
Tujuan dari penelitian ini menganalisis dampak kapitalisasi sewa operasi berdasarkan PSAK 73 yang berlaku dalam penyusunan laporan keuangan terkait dengan kegiatan Lease (Sewa Hak Guna). Dampak dalam penerapan PSAK 73 konvergensi dari IFRS 16 memperkenalkan model akuntansi tunggal yang berlaku pada pihak Lessee, sedangkan bagi pihak Lessor tidak terdapat perbedaan dengan standar yang sebelumnya. Jenis penelitian yang digunakan dalam penelitian ini adalah penelitian kuantitatif dengan data yang digunakan adalah data sekunder dengan memanfaat data yang tersedia pada laporan tahunan serta laporan keuangan perusahaan yang terdaftar di Bursa Efek Indonesia, periode 2018-2019. Data sekunder diambil dari data perusahaan yang mengungkapkan nilai sewa pembayaran minimum masa depan mengenai operating lease pada laporan keuangan perusahaan. Sampel penelitian adalah perusahaan tercatat di Bursa Efek Indonsia periode 2018-2019). Metode analisis data adalah pengujian statistic deskriptif dan uji Paired T-Test dan uji Anova dengan menggunakan Software Aplikasi statistic Minitab 16. Hasil penelitian ini menunjukkan bahwa kapitalisasi sewa operasi memiliki pengaruh signifikan terhadap unrecorded lease liability, unrecorded lease assets, ekuitas, dan rasio keuangan dari kapitalisasi sewa operasi.
\end{abstract}

Kata Kunci: PSAK 73, Sewa Operasi, Constructive Capitalization, Laporan Keuangan 


\section{Pendahuluan}

Indonesia merupakan salah satu negara yang sedang berkembang, dalam menghadapi era globalisasi saat ini, persaingan semakin ketat dan perekonomian terus bertumbuh cukup pesat serta stabil. Perusahan berdiri tidak hanya untuk mencari keuntungan saja, tetapi dari keuntungan yang diperoleh tersebut dapat membantu perusahaan untuk dapat bertahan sekaligus mampu bersaing dengan tujuan dalam pengembalian modal atas investasi yang diberikan oleh para investor dalam menaruh kepercayaan pada perusahaan dalam mengolah dana yang mereka tanamkan untuk dapat dikembangkan. Salah satu indicator untuk dapat menilai kinerja perusahaan adalah dengan mengevaluasi informasi perusahaan berupa informasi laporan keuangannya. Dalam Standar Akuntansi Keuangan yang berlaku, yaitu PSAK 01 (2018), menjelaskan laporan keuangan memberikan informasi entitas terkait dengan aset, liabilitas, ekuitas, penghasilan dan beban, kontribusi dari dan distribusi kepada pemilik dalam kapasitasnya sebagai pemilik, serta arus kas. Berdasarkan informasi tersebut, digunakan untuk menghitung rasio-rasio keuangan yang membantu mengetahui bagaimana posisi keuangan dan keberhasilan perusahaan dalam periode tersebut.

Dalam meningkatkan kinerja perusahaan, salah satu langkah yang dapat diambil adalah perusahaan dalam melakukan perbaikan dan improvisasi dalam operasional kegiatan perusahaan sehingga hasil yang akan diperoleh adalah oerganisasi dapat berjalan secara efisein dan efektif. Dalam membantu kelancaran operasional, perusahaan membutuhkan aset tetap (fixed assets) yang digunakan untuk menghasilkan barang maupun jasa, untuk keperluan administrasi, untuk disewakan, dan lain sebagainya. Hal tersebut sesuai dengan Oxtaviana dan Khusbandiyah (2016), yang menjelaskan bahwa asset tetap digunakan dalam memberikan dukungan pada perusahaan dalam penyediaan barang dan jasa. Dukungan tersebut terdapat dalam kegiatan penyewaan untuk tujuan administrasi dan dimanfaat dalam jangka waktu yang panjang atau lebih dari satu tahun dan selama periode operasional perusahaan sehingga dapat membantu perusahaan dalam meningkatkan profitabiltas.

Perolehan asset tetap menuntut perusahaan untuk memiliki dana yang cukup besar, karena harga asset tetap cenderung memiliki yang mahal dan tinggi. Sehingga atas dasar tersebut perusahaan menggunakan alternative lain untuk dapat menggunakan manfaat ekonomis asset tetap tersebut dengan cara pengadaan melalui perusahaan pembiayaan dibidang sewa. Terdapat beberapa keuntungan perusahaan melakukan pengadaan dalam kegiatan sewa, yaitu diantaranya pembiayaan sewa cenderung murah dibandingnya dengan metode pembiayaan lainnya seperti pembeliaan asset atau melakukan pinjaman dari perbankan untuk dapat memperoleh asset tersebut. Dan keuntungan lain dari perolehan asset melalui sewa adalah alu terhindar dari keusangan akibat kemajuan teknologi, serta leasing dapat memberikan keuntungan pajak karena perusahaan dapat memanfaatkan dan mendepresiasi aset sewaan untuk mengurangi penghasilan kena pajak (PKP) (Martani, dkk, 2016).

Selain itu juga perusahaan pembiayaan di bidang sewa saat ini sedang berkembang cukup pesat. Hal tersebut dapat diketahui data data Otoritas Jasa Keuangan (2019), ), total asset yang dimiliki oleh perusahaan pembiayaaan terus meningkat hingga bulan Oktober 2019 kuartal 3 atau bulan Oktober 2019 menjadi sebesar Rp 516,929 Miliar dari total asset periode yang sama tahun lalu sebesar Rp 511,106 Miliar terjadi peningkatan sebesar 5,822\%. Sehingga dengan terus meningkatnya jumlah permintaan serta penawaran dari kegiatan sewa menyewa atas asset tetap dan asset berwujud lainnya menuntut pemerintah serta para pelaku kegiatan bisnis untuk 
dapat mewujudkan pedoman yang mengatur kegiatan sewa dalam pengakuan, pengukuran, penyajian serta pengungkapan yang berlaku pada seluruh perusahaan yang terdaftar di Indonesia.

Kegiatan Sewa guna usaha atau Leasing bermula pada tahun 1974. Dengan diterbitkannya surat keputusan bersama Menteri Keuangan, Menteri Perdagangan dan Menteri Perindustrian No. Kep-1221 MK/02/1974, No. 321 MISKI 2.1974 dan No. 30/KPB/I/1974 tertanggal 07 Februari 2974, peraturan tersebut mengenai "Perizinan kegiatan usaha Leasing". Pada tahun 1980 adalah awal mula diterbitkannya surat keputusan perizinan kegiatan usaha sewa menyewa, sehingga jumlah kegiatan usaha sewa guna usaha pun turut serta berkembang dan meningkat jumlahnya. Semakin lama Perusahaan mulai bermuncullan untuk mendukung proses bisnis sewa guna usaha dalam mendanai penyediaan barang-barang modal dunia usaha. Sebelum tahun 2020, di Indonesia, pengakuan, pengukuran, penyajian dan pengungkapan atas sewa pada laporan keuangan perusahaan go public diatur pada Pernyataan Standar Akuntansi Keuangan Nomor 30 (PSAK No.30) atas Sewa. Namun seiring berjalannya waktu standar tersebut mulai dikritisi oleh pengguna laporan keuangan (stakeholders) karena tidak selalu merefleksikan dengan tepat transaksi leasing yang dilakukan oleh perusahaan. Model akuntansi sewa yang ditetapkan sebelumnya pada PSAK ini mensyaratkan lessee maupun lessor untuk mengklasifikasikan sewanya sebagai operating lease maupun capital lease serta melakukan pencatatan secara berbeda atas kedua jenis sewa.

Menurut PSAK 30, sewa pembiayaan (capital lease) terjadi apabila terdapat pengalihan secara substansial terkait risiko dan manfaat aset, dan atas sewa tersebut entitas mengakui dan mencatatnya pada laporan posisi keuangan sebagai aset hak guna dan liabilitas sewa. Sebaliknya, jika secara substansial risiko dan manfaat yang terkait dengan kepemilikan aset tidak dialihkan, maka sewa dikategorikan sebagai operating lease. Model sewa operasi tidak mensyaratkan lessee untuk mengakui aset dan liabilitas yang timbul dari sewa operasi pada laporan posisi keuangan. Kondisi seperti itu dikenal dengan istilah off balance sheet yaitu, akun aset atau liabilitas yang secara efektif merupakan aset dan liabilitas perusahaan pada tanggal tertentu, tidak muncul pada laporan posisi keuangan perusahaan, sehingga apabila menerapkan metode tersebut akan berdampak pada rasio keuangan khususnya rasio efisiensi dan leverage agar terlihat lebih baik.

Terdapat beberapa keuntungan nanti yang akan diperoleh oleh peusahaan dalam mengklasifikasikan kegiatan operasionalnya dalam operating lease. Menurut penelitian Nuryani, et al (2015), aktivitasi sewa operasi tidak dapat mengindentifikasi determinsasi ekonomi dengan jelas, sehingga berdampak pada kegiatan manajamen laba yang akan dilakukan oleh manajer perusahaan. Manajer perusahaan akan terdorong untuk memanfaatkanm sewa operasi sebagai kegiatan off balance sheet untuk dapat menyembunyikan jumlah hutang perusahaan. Hal tersebut terjaidi pada kasus PT Garuda Indonesia. Dilansir dari laman Kompas.com yang ditulis oleh Narita Indrastiti, PT Garuda melakukan belanja pesawat besar-besaran dengan menggunakan skema lease. Pembelian sebanyak 90 pesawat baru di Paris Air Show, 80 persen diantaranya menggunakan skema operating lease dengan total nilai transaksi pembelian US\$ 20 miliar atau setara dengan Rp 267 triliun. Penjelasan tersebut disampaikan oleh Direktur keuangan PT Garuda Indonesia Tbk. yaitu I Gusti Ngurah Askhara Danadiputra yang dihubungi KONTAN, Rabu (17/6/2015). Skewa sewa sale and lease back oleh PT Garuda Indonesia ini, yaitu maskapai melakukan penjualan pesawat yang telah dibeli dan langsung menyewa kembali dari lessor. 
Dengan begitu PT Garuda Indonesia tidak perlu mencatat aset maupun liabilitas sewa atas pengadaan aset pada laporan posisi keuangan, sehingga rasio keuangan perusahaan tetap terjaga.

Diperoleh dari laman Kompas.com, kasus terkait sewa juga dialami maskapai penerbangan PT Metro Batavia. Maskapai tersebut (Batavia Air) oleh Pengadilan Niaga Jakarta Pusat, pada Rabu (30/1/2013) dinyatakan pailit. Putusan ini bermula dari gugatan perusahaan leasing pesawat International Lease Finance Corporation (ILFC) karena Batavia Air tak kunjung membayar kewajibannya. Adapun data utang Batavia Air mencapai $\mathrm{Rp}$ 1,25 triliun, yang sebagian besar merupakan hutang sewa guna usaha senilai Rp 500 miliar, sisanya Rp 95 miliar utang pada penumpang dan agen pemegang tiket, Rp 230 miliar utang bank, Rp 60 miliar utang pajak, dan Rp 140 miliar utang karyawan. Dari informasi tersebut, dapat dilihat bahwa leasing mungkin salah satu metode pembiayaan yang cukup banyak digunakan, terutama bagi perusahaanperusahaan yang memerlukan aset bernilai tinggi dalam menjalankan operasionalnya, karena dengan leasing diharapkan perusahaan mampu mengalokasikan dananya untuk kegiatan operasional lain.

Atas dasar salah satu kasus diatas mengenai kegiatan sewa yang dilakukan oleh perusahaan, maka dapat dijadikan salah satu faktor untuk merevisi PSAK 30. Karena PSAK 30 dalam menunjukkan transaksi leasing perusahaan tidak dapat menunjukan representasi yang tepat atas kegiatan sewa. Sebagai bentuk komitmen Standar Akuntansi Keuangan yang berlaku di Indonesia untuk melakukan konvergensi IFRS secara penuh, maka pada 18 September 2017 Dewan Standar Akuntansi Keuangan Ikatan Akuntan Indonesia (DSAK IAI) mengesahkan PSAK 73: Sewa. Hal tersebut dapat dilihat pada laman berita IAI, yang menyatakan bahwa per tanggal tersebut Draf Eksposur (DE) PSAK 73 telah disahkan menjadi PSAK 73: Sewa yang merupakan adopsi dari IFRS 16 Leases. PSAK ini menggantikan standar terkait sewa yang ditetapkan sebelumnya pada PSAK 30. PSAK 73 berlaku efektif pada 1 Januari 2020, namun Ikatan Akuntan Indonesia (IAI) memperbolehkan adanya penerapan dini dengan syarat entitas telah menerapkan PSAK 72: Pendapatan dari Kontrak dengan Pelanggan.

PSAK 73 atas sewa bertujuan untuk memperkenalkan bagi penyewa (lessee) suatu model akuntansi tunggal, yaitu mengklasifikasikan sewanya sebagai sewa pembiayaan. Terdapat dua pengecualian bagi pihak leasee agar tetap dapat mengkategorikan perjanjian leasingnya sebagai operating lease yaitu apabila masa sewa kurang dari 12 bulan atau aset pendasarnya (underlying assets) bernilai rendah. Jika aset yang mendasari biasanya bernilai tinggi saat baru, aset tersebut tidak dapat diklasifikasikan sebagai sewa dari aset bernilai rendah, misalnya saja mobil bekas yang disewa oleh lessee. Contoh dari aset pendasar bernilai rendah yaitu laptop, peralatan kantor, dan telepon. Sedangkan, bagi pihak pesewa (lessor), karena tidak adanya perubahan aturan, mereka tetap mengklasifikasikan sewanya sebagai sewa pembiayaan maupun sewa operasi.

Mulai berlakunya PSAK 73 pada tahun 2020 tentunya akan berdampak pada laporan keuangan perusahaan, karena mereka diwajibkan untuk mengkapitalisasikan komitmen sewa operasi yang dimilikinya dan melaporkannya sewa tersebut pada laporan posisi keuangan sebagai aset hak guna (right of use asset) dan liabilitas sewa. Dampak dari kapitalisasi sewa operasi tersebut juga pernah diteliti sebelumnya, oleh Wong \& Joshi (2015), Bennett \& Bradbury (2003), dan Öztürk \& Serçemeli (2016) dengan menggunakan metode constructive capitalization yang dikembangkan Imhoff, et al (1991).

Penelitian oleh Wong \& Joshi (2015) bertujuan untuk menganalisis dampak kapitalisasi sewa operasi terhadap laporan 
keuangan dan rasio keuangan pada 107 perusahaan yang listing di Australian Stock Exchange. Hasil penelitian menunjukan bahwa terdapat pengaruh signifikan terhadap financial statement dan financial ratio setelah dilakukan kapitalisasi sewa. Rata-rata DER meningkat sebesar 0,258 atau 31,69\%, dan DAR meningkat sebesar 0,046 atau $10,11 \%$. Sedangkan untuk profitabilitas, return on asset (ROA) turun tajam sebesar $15,35 \%$ dan ROE turun 0,0033 atau ratarata $1,23 \%$. Penelitian terkait kapitalisasi sewa operasi juga pernah dilakukan Bennett dan Bradbury (2003) dengan judul "Capitalizing Non-cancelable Operating leases" pada 38 perusahaan yang terdaftar di New Zealand Stock Exchange. Pengukurannya menggunakan model kapitalisasi konstruktif yang dikembangkan oleh Imhoff, et al (1991). Hasilnya menunjukan kapitalisasi sewa memiliki dampak yang material terhadap liabilitas dan rasio keuangan. Rata-rata liabilitas sewa yang tidak dilaporkan sebesar $22,9 \%$ dari total liabilitas, dan equity mengalami penurunan sebesar $3 \%$. Penelitian serupa juga dilakukan oleh Öztürk dan Serçemeli (2016) pada perusahaan penerbangan di Turki. Hasilnya menunjukan estimasi jumlah liabilitas sewa yang tidak dilaporkan sebagai dampak kapitalisasi sewa sebesar 1 1,427,860,777, dan pengaruhnya terhadap laporan posisi keuangan yaitu liabilitas mengalami peningkatan sebesar $52,2 \%$, ekuitas turun $12,5 \%$, sedangkan aset mengalami peningkatan $29,3 \%$.

Berdasarkan uraian tersebut, penelitian ini dengan judul "penerapan kapitalisasi sewa operasi terhadap laporan posisi keuangan dan rasio keuangan pada perusahaan di indonesia" ini dilakukan dengan tujuan memberikan pengetahuan bagi pengguna laporan keuangan bagaimana pengaruh kapitalisasi sewa operasi terhadap laporan keuangan. Penelitian ini dapat memberikan informasi tambahan secara literature mengenai penerapan kapitalisasi sewa menurut
PSAK 73 yang beru atas lease terhadap kinerja keuangan pada perusahaan yang tergambarkan dalam laporan posisi keuangan dan rasio keuangan yang digunakan dalam penelitian ini.

\subsection{Perumusan Masalah}

Sesuai dengan latar belakang penelitian yang telah dilampir, maka dapat perumusan permasalahan dalam penelitian ini adalah untuk mengetahui :

a. Apakah kapitalisasi lease memiliki dampak dalam total asset, total liabilitas dan total ekuitas pada pencatatan dalam laporan posisi keuangan.

b. Apakah kapitalisasi lease memiliki dampak terhadap Kinerja Keuangan?

\subsection{Tujuan Penelitian}

Berdasarkan perumusan masalah yang diuraikan di atas, maka penelitian ini mempunyai tujuan sebagai berikut :

a. Untuk menguji secara empiris dampak kapitalisasi terhadap total asset, total liabilitas dan total ekuitas pada laporan Posisi Keuangan

b. Untuk menguji secara empiris dampak Kapitalisasai lease terhadap Kinerja Keuangan.

\section{LANDASAN TEORITIS}

Berikut akan dijelaskan teori yang menjadi dasar dalam penelitian ini, serta beberapa teori pendukung yang menjelaskan secara spesifik terkait variabel yang akan diteliti dalam penelitian ini.

Aset tetap merupakan salah satu pendukung kegiatan perusahaan agar dapat berjalan dengan lancar dan kegiatan operasional perusahaan dapat menjalankan berbagai aktivitas perusahaannya dengan efektif dan effesien. Aset tetap dapat diperoleh oleh persuahaan dengan melalui pembelian dan merakit sendiri. Namun nharga peroleh asset tetap yang cukup mahal dan tinggi, membuat perusahaan 
untuk menggunakan alternative lain dalam memperolehnya. Salah satu caranya adalah kegiatan sewa, dengan alasan agar perusahaan dalam penggunaan anggaran dapat mengalokasikan sebagian dananya pada dana dalam mendukung kegiatan operasional perusahaan lainnya. Terdapat beberapa keuantungan yang dapat dimanfaatkan dala kegiatan sewa, yaitu diantara harga yang ditawarkan biasanya lebih murah jika dibandingkan metode pendanaan perolehan asset tetap lainnya. Selain itu kegiatan sewa juga dapat membantu perusahaan terhindar dari keusangan dan kerusakaan atas asset tetap tersebut, dan adanya pendanaan off balance sheet. Seperti pada kasus PT Garud Indonesia, telah terindentifikasi kegiatan off balance sheet, dimana PT Garuda tidak melakukan perlaporan asset dan liabilitasnya sewaannya pada Financial Statement. Hal tersebut ditunjukkan dengan pembeliaan 90 pesawat baru di Paris Air Show dengan total harga mencapai Rp 267 Triliun, dan ternyata 80 persen dari pembelian asset tersebut diklasifikan menjadi sewa dengan skema operating lease yang tujuannya untuk menghindari harga liabilitas atas pembelian secara kredit dari pembelian pesawat baru tersebut. Dan menghindari diakuinya asset tersebut sebagai asset berwujud dalam laporan posisi keuangan perusahaan, yang berdampak pada kinerja perusahaan dalam rasio efisiensi dan leverage perusahaan.

Sebagai komitmen konvergensi penuh terhadap IFRS, DSAK IAI pada tanggal 18 September 2017 mengesahkan PSAK 73 mengenai Sewa, yang merupakan adopsi dari IFRS 16 Leases. PSAK 73 telah berlaku efektif mulai 01 Januari 2020, menggantikan standar yang terkait dengan sewa yang sebelumnya diatur pada PSAK 30. Standar tersebut digantikan karena tidak selalu merepresentasikan dengan tepat atas transaksi sewa guna yang dilakukan oleh perusahaan. Model akuntansi sewa pada PSAK 30, mensyaratkan bagi penyewa (lessee), untuk mengklasifikasikan sewanya sebagai operating lease maupun capital lease.

PSAK 73 atas sewa bertujuan untuk memperkenalkan bagi penyewa (lessee) suatu model akuntansi tunggal, yaitu mengklasifikasikan sewanya sebagai sewa pembiayaan. Sedangkan bagi pihak lessor, karena tidak adanya perubahan aturan maka tetap mengklasifikasikan sewanya sebagai operating lease maupun capital lease. Mulai berlakunya PSAK 73 pada tahun 2020 tentunya akan berdampak pada laporan keuangan perusahaan, karena lessee diwajibkan untuk mengkapitalisasikan komitmen sewa operasi yang dimilikinya dan melaporkannya sewa tersebut pada statement of financial position sebagai aset hak guna (right of use aset) dan liabilitas sewa.

Nuryani, et al (2015) melakukan penelitian dengan judul "Capitalization of Operating lease and Its Impact on Firm's Financial ratios" pada 19 perusahaan yang terdaftar di Bursa Efek Indonesia tahun 2008-2011. Penelitian tersebut bertujuan untuk menguji determinan dari kebijakan sewa operasi (yaitu kendala keuangan, nilai aset, pertumbuhan, dan ukuran perusahaan), dan pengaruh kapitalisasi konstruktif sewa operasi terhadap rasio keuangan. Pengukurannya menggunakan model multiple linier regression dan uji komparatif. Temuan menunjukkan bahwa semua faktor determinan (kecuali kendala keuangan) mempengaruhi kebijakan sewa operasi, tetapi sebagian besar sewa operasi dijelaskan oleh faktor selain determinan ekonomi. Studi ini juga menemukan bahwa Semua rasio keuangan kecuali Return on Equity (ROE) berbeda secara signifikan antara sebelum dan sesudah dilakukan kapitalisasi sewa operasi.

Dampak kapitalisasi juga memiliki pengaruhnya dalam penelitian Safitri, dkk (2019)d engan judul "Analisis Dampak Penerapan PSAK 73 Atas Sewa Terhadap Kinerja Keuangan Pada Industri Manufaktur, Pertambangan dan Jasa yang Terdaftar di Bursa Efek Indonesia Tahun 
2018" juga dilakukan untuk melihat dampak kapitalisasi sewa karena dikeluarkannya standar baru PSAK 73. Hasilnya menunjukan dampak terbesar kapitalisasi sewa terhadap rasio keuangan terjadi pada industri jasa $(233,72 \%)$, disusul pertambangan $(6,90 \%)$, dan terakhir industri manufaktur $(3,90 \%)$.

Berdasarkan uraian tersebut penelitian ini bertujuan untuk menganalisis perubahan kapitalisasi sewa operasi terhadap laporan keuangan, rasio keuangan, dan menghitung besarnya penghematan pajak yang akan diperoleh perusahaan apabila mengkategorikan sewanya sebagai capital lease. Berdasarkan pada identifikasi masalah dan tinjauan pustaka berupa kajian teoritis dan penelitian empiric terdahulu, maka dapat digambarkan model hipetesis sebagai berikut:

\subsection{Dampak Kapitalisasi Sewa pada Laporan Posisi Keuangan}

Dalam mengklasifikasikan asset sewanya dalam jenis sewa operasinya (Operating lease), perusahaan tidak perlu melakukan pencatatan dan pengakuan atas asset tersebut dalam akun asset maupun liabilitas atas sewa pada laporan posisi keuangannya. Asset atas sewa operasional akan diakui sebagai beban sewa, yang menjadi beban perusahaan. Beban sewa tersebut akan diakui seluruhnya pada laporan laba rugi pada tahun berjalan yang akan berdampak pada pengurangan pendapatan adan akan mempengaruhi akun ekuitas pada laporan posisi keuangan.

Perusahaan tidak hanya mengakui liabilitas sewa saja, tetapi dampak kapitalisasi akan berdampak pada pengakuan Aset Hak Guna. Besarnya aset sewa yang dimiliki oleh perusahaan tergantung dari besarnya komitmen sewa operasi yang dimiliki oleh perusahaan. Asset sewa akan mengalami penurunan pada tingkat yang lebih rendah dibanding liabilitas sewa, karena aset sewa akan mengalami penyusutan pada jumlah yang lebih besar akibat diakuinya asset sewa yang dapat dimiki pada akhir masa sewa sehingga, penyusutan atas asset sewa harus diakui dan diperhitungkan. Pernurunan asset sewa akan terjadi lebih cepat dibanding penurunan liabilitas sewa.

Dalam PSAK 30 atas Sewa (2018) menjelaskan bahwa kegiatan sewa kategori operasi tidak memberikan kewajiba bagi penyewa untuk mengakui adanya akun asset dan liabilitas. Dan hal tersebut bertentangan dalam kerangka konseptual pelaporan keuangan terkait penyajian jujur dalam fundamental karakteristik kualitatif. Sehingga, DSAK IAI sejalan dengan

berisikan mengenai sewa operasi yang tidak mewajibkan penyewa untuk mengakui asset dan liabilitas. Sehingga bertentangan dengan konsep penyajian jujur dalam fundamental karakteristik kualitatif. Oleh sebab itu, DSAK IAI sejalan dengan konsep konvergensi IFRS 16 segera menerbitkan PSAK 73 yang telah berlaku efektif tahun 2020, menselaraskan pengakuan, pengukuran dan penyajian serta pengungkan atas sewa terutama dalam sisi penyewa (lessee). Dimana PSAK 73 mewajibkan dari sisi penyewa untuk menerapkan sewa jenis pembiayaan atau yang lebih dikenal dengan Financial Lease (Safitri, dkk,2018). Kegiatan sewa menurut PSAK 73, mewajibkan seluruh asset yang masuk dalam kategore operasi, untuk dapat dilakukan pengakuan, pengukuran dan pengukapan secara retrospesktif akibat dampak dari perubahan kebijakan akuntansi (PSAK 25).

Hasil penelitian yang dilakukan oleh Bennett dan Bradbury (2003) pada 38 perusahaan yang listing di New Zealand Stock Exchange dan Duke, et al (2009). Serta Penelitian pada perusahaan penerbangan di Turki oleh Öztürk dan Serçemeli (2016) juga membuktikan bahwa terdapat jumlah yang cukup material dari liabilitas sewa yang tidak dilaporkan oleh perusahaan dampak setelah terjadinya kapitalisasi sewa cukup berpengaruh signifikan, yaitu sebesar $52 \%$. Berdasarkan penjelasan tersebut, maka dirumuskan hipotesis sebagai berikut. 


\section{$\mathrm{H}_{1}$ : Kapitalisasi sewa berpengaruh terhadap Laporan Posisi Keuangan.}

\subsection{Dampak Kapitalisasi Sewa pada Kinerja Keuangan}

Salah satu indicator untuk menganalisa laporan keuangan adalah dengan memperhitungkan rasio keuangan. Rasio keuangan dapat digunakan sebagai media informasi baru stakeholder dan shareholder untuk pengambilan keputusan terkait dengan kebijakan operasional perusahaan. Dalam mengukur kinerja perusahaan dapat dilakukan dengan cara membandingkan akun perusahaan dengan akun lainya pada laporan keuangan. Dampak kapitalisasi sewa operasi akan memperngaruhi nominal saldo laporan keuangan, dan selaras dengan adanya perubahan rasio keuangan. Beberapa penilitian terdahulu menyebutkan terdapat pengaruh yang signifikan adanya perubahan kebijakan akuntansi yang baru terhadap pelaporan keuangan. Salah satunya adalah PSAK 30 yang dikonvergensi menjadi PSAK 73. Penelitian yang menyebutkan adanya pengaruh sebelum dan sesudah kapitalisasi sewa operasi signifikan pada rasio keuangan adalah penelitian yang dilakukan oleh Nuryani, dkk (2015), Wong and Joshi (2015), Safitri, dkk (2019), Öztürk dan Serçemeli (2016). Rata-rata menyatakan bahwa rasio solvabilitas mengalami kenaikan yang signifikan karena adanya pengakuan liabilitas sewa pada laporan posisi keuangan, sedangkan pada rasio profitabilitas mengalami penurunan karena pengakuan beban yang lebih tinggi yang berakibat pada penurunan net income. Penelitian Wong dan Joshi (2015) pada 107 perusahaan yang terdaftar di Australian Stock Exchange menyatakan setelah dilakukannya kapitalisasi sewa DER rata-rata meningkat sebesar 0,258 atau $31,69 \%$, dan DAR meningkat sebesar 0,046 atau $10,11 \%$. Sedangkan untuk profitabilitas, return on asset (ROA) turun tajam sebesar $15,35 \%$ dan ROE rata-rata turun sebesar 0,0033 atau $1,23 \%$. Untuk mengetahui lebih lanjut terkait dengan sebelum dan sesudah kapitalisasi sewa operasi maka hipotesis yang terbentuk adalah dampak kapitalisasi kapitalisasi sewa pada beberapa rasio keuangan yang terpilih:

\section{H2: Kapitalisasi sewa operasi} berpengaruh terhadap rasio keuangan

\section{METODE PENELITIAN Definisi Operasional dan Pengukuran Variabel}

Penelitian ini diharapkan secara harfiah dapat dimanfaatkan dan beguna. Sehingga untuk mencapai hal tersebut maka perlu pengukuran secara empiris dan mendefinisikan pengukuran untuk menghindari terjadinya kesalahan penafsiran. Setiap Variabel Dependen dan Independen pada penelitian ini dapat didefinisikan dan diukur sebagai berikut:

\section{a. Variabel Independen (X)}

Variabel Dependen yang digunakan dalam penelitian ini adalah kapitalisasi sewa operasi sesuai dengan PSAK 73 Leases. Dimana Variabel kapitalisasi sewa operasi yang digunakan merupakan suatu perjanjian yang dilakukan antara Penyewa (lessee) sebagai pihak yang memanfaatkan secara ekonomis dari asset sewa yang dimiliki dengan memenuhi janji bayar kepada pihak penyewa (lessor) dengan syarat yang sudah disepakatai di awal janji kontrak tersebut.

Metode yang digunakan dalam pengukuran kapitalisasi sewa adalah metode Kapitalisasi Konstruktif yang telah dikembangkan oleh Imhoff et al (1991), Metode tersebut telah diterima secara umum dan diterapkan diberbagai penelitian seperti oleh Beattie et.al. (1998), Bennet \& Bradbury (2003), Duke, et al (2012), Tai (2013), Wong dan Joshi (2015), Öztürk \& Serçemeli (2016).

b. Variabel Independen (Y1)

1. Unrecorded Lease Liability

Liabilitas Sewa diperhitungkan dengan mengukur nilai kini atas arus kas 
dimasa yang akan datang dalam kegiatan sewa operasi. Berdasarkan PSAK 30 paragraf 31(b), dalam pengungkapan yang dilakukan pada akhir periode pelaporan, pihak Lesse diwajibkan mengungkapkan total terjadinya pembayaran sewa minimum dimasa yang akan datang. Untuk menghitung jangka waktu sewa penelitian ini mengikuti literatur sebelumnya (Imhoff, 1991, 1997) yang membagi pembayaran sewa agregat selama lima tahun dan memperkirakan berapa tahun pembayaran sewa akan berlanjut. Penelitian ini mengasumsikan masa sewa maksimum 10 tahun seperti yang digunakan oleh Bennet et al (2003). Dalam perhitungan bunga sewa pembiayaan, asumsi bunga dapat menggunakan bunga imprest jika dapat diperhitungkan secara handal. Namun jika tidak diketahui perhitungan bunga imprest, maka diperkenankan untuk menggunakan bunga incremental. Namun, perhitungan bunga yang terlampir tidak diketahui maka tingkat suka bunga yang digunakan adalah $10 \%$, hal tersebut sesuai dengan penelitian sebelumnya (Beattie et.al., 1998; Imhoff et.al., 1991; Duke et.al., 2009; Wong dan Joshi, 2015). Untuk menghitung Net unrecorded lease liability (Net URL), digunakan rumus berikut:

$$
\text { Net URL }=U R L-(U R L-U R A \times \text { TRt })
$$

Keterangan:

$$
\begin{array}{ll}
\text { URL } & =\quad \text { Unrecorded Lease } \\
\text { Liability } & \\
\text { URA } & =\text { Unrecorded Lease Assets } \\
\text { TRt } & =\text { Tarif pajak tahun berjalan }
\end{array}
$$

\section{Unrecorded Leases Assets}

Aset sewa merupakan nilai manfaat dimasa yang akan datang yang dapat digunakan oleh perusahaan dalam penggunaan asset sewa pembiayaan. Dalam sewa operasi, asset lease tidak dapat ditunjukkan dalam laporan posisi keuangan perusahaan. Nilai unrecorded lease assets tergantung pada total nilai yang dapat ditnjukkan pada nominal arus kas, tingkat suku bunga, dan sisa masa sewa. Mengikuti penelitian sebelumnya (Bennet et al, 2003), dengan asumsi masa sewa maksimum 10 tahun, suku bunga $10 \%$, dan $50 \%$ dari masa sewa telah kadaluarsa (digunakan), maka rasio aset terhadap kewajiban sebesar $81 \%$. Rasio aset terhadap liabilitas (proporsi aset) dirumuskan sebagai berikut:

$$
\frac{P V_{A}}{P V_{L}}=\frac{R L}{T L} \times \frac{P V A F_{\% r, T L}}{P V A F_{\%, r}, R L}
$$

Keterangan:
PVA = Present Value of
Unrecorded Asset
PVL = Present Value of
Unrecorded Liability
RL = Remaining Life
TL = Total Lease Life
PVAF = Present Value Annuity
Factor

\section{Unrecorded Equity}

Perubahan nilai dari Ekuitas, merupakan dampak dari adanya perubahan laporan posisi keuangan sebagai akibat munculnya asset hak guna dan liabilitas sewa. Perhitungan yang dilakukan pada saat nilai sewa atas asset dan liabilitas atas sewa menghasilkan selisih berdampak pada besarannya atas perubahan ekuitas. Pengakuan beban yang besar karena diakibatkan adanya beban depresasi dan beban bunga yang harus dibebankan pada laporan laba rugi perusahaan setiap periodenya akan berdampak pada jumlah nilai ekuitas yang sejalan menurun. Perubahan pada ekuitas dirumuskan sebagai berikut:

Perubahan Ekuitas=1-TR $\mathrm{x}($ URL-URA)

Keterangan:
$\mathrm{TR}=$ Tax Rate
URL = Unrecorded Lease Liability
URA = Unrecorded Lease Assets 
c. Variabel Independen (Y2), Rasio Keuangan

Setelah pengukuran nilai asset sewa dan liabilitas sewa telah dilakukan sesuai dengan kapitalisasi atas sewa operasi, maka dampak tersebut dapat dilihat dari laporang keuangan dengan menggunakan beberapa rasio. Rasio tersebut diantaranya adalah:

1. Rasio Solvabilitas:

Variabel Solvabilitas adalah merupakan kinerja keuangan untuk mempertimbangkan seberapa besar atau banyaknya jumlah aset perusahaan yang dibiayai dengan menggunakan utang dalam menjalankan kegiatan operasional perusahaan (Kasmir, 2010).

Pengukuran Solvabilitas yang digunakan adalah:

$$
\begin{aligned}
\text { DAR } & =\frac{\text { Total Utang }}{\text { Total Aset }} \\
\text { Dan } & \\
\text { DER } & =\frac{\text { Total Utang }}{\text { Total Ekuitas }}
\end{aligned}
$$

2. Rasio Profitabilitas

Variabel Profitabilitas adalah suatu indikator yang mengukur sejauh mana perusahaan memiliki kemampuan dalam menjalankan kegiatan operasional dan menghasilan laba bersih sebagai tolak ukur keberhasilan kinerja manajemen (Hery, 2017). Pengukuran Profitabilitas yang digunakan adalah:

$$
\begin{gathered}
R O A=\frac{\text { Laba Bersih Setelah Pajak }}{\text { Total aset }} \\
\text { Dan } \\
R O E=\frac{\text { Laba Bersih Setelah Pajak }}{\text { Total Ekuitas }}
\end{gathered}
$$$$
\text { Populasi }
$$

Penelitian ini menggunakan populasi seluruh perusahaan yang listing di Bursa Efek Indonesia dengan periode penelitian adalah tahun 2018 dan 2019.

\section{Sampel}

Dalam pengambilan sampel penelitian ini menggunakan metode Purposive Sampel. Sampel yang diguna-kan dengan pendekatan penentuan kriteria disesuaikan dengan kebutuhan penelitian berikut. Adapun kriteria dalam penentuan sampel ini adalah sebagai berikut:

1. Perusahaan yang terdaftar di BEI periode 2018 dan 2019

2. Perusahaan yang menerbitkan laporan tahunan yang telah diaudit dan menunjukkan pencatatan operating lease dalam kegiatan sewa atas keseluruhan asset.

3. Perusahaan yang mengungkapkan komitmen sewa dengan menunjukkan pembayaran lease pada periode penelitian.

\section{Metode Pengumpulan Data}

Metode pengumpulan data yang digunakan dalam penelitian ini adalah sebagai berikut:

1. Penelitian Lapangan (Field Research)

2. Penelitian Kepustakaan (Library Research)

\section{Metode Analisis Data}

Teknik analisis deskriptif kuantiatif digunakan dalam metode analisis data penelitian ini dengan $T$ Paired untuk mengetahui perbedaan yang signifikan antar sebelum dan sesudah adanya kapitalisasi sewa operasi dalam laporan keuangan perusahaan.

Alat uji yang digunakan dalam penelitian ini adalah Uji Statistik Deskriptif, Uji Hipotesis dengan menggunakan Uji Wilcoxon signed Rank Test. Uji tersebut merupakan alternative uji Pairing $t$ test atau $t$ paired, pada saat tidak terpenuhinya asumsi normalitas.

Dengan mengacu pada beberapa penelitian yaitu Inhoff, et el (1991), dalam penerapan metode analisis yang digunakan adalah metode kapitalisasi konstruktif sewa dan telah dilakukannya modifikasi pada penelitian oleh Öztürk \& Serçemeli (2016). 
Metode kapitalisasi konstruktif sewa ini digunakan untuk mengetahui jumlah aset sewa, kewajiban sewa, serta pada elemen laporan keuangan lainnya yang tidak tercatat pada laporan keuangan perusahaan sebagai dampak dari kapitalisasi sewa operasi.

Langkah-langkah yang dilakukan untuk menganalisis data dalam penelitian ini adalah sebagai berikut:

1. Perhitungan Data

Berikut langkah-langkah dalam melakukan perhitungan data pada penelitian ini:

a. Menghitung nilai sekarang (present value) dari pembayaran sewa operasi dimasa depan. Dari catatan atas laporan keuangan (CALK) dapat diperoleh informasi mengenai komitmen sewa operasi perusahaan, kemudian dilakukan perhitungan minimum lease payment.

b. Menghitung liabilitas sewa dan nilai aset leasing yang baru

c. Menghitung tax deduction

d. Menghitung nilai equity

e. Menambahkan nilai aset dan liabilitas tambahan yang sudah diketahui pada laporan posisi keuangan

f. Setelah itu dilakukan perhitungan untuk melihat dampaknya pada laporan keuangan antara sebelum dan setelah dilakukan kapitasi sewa operasi.

2. Menganalisis Data

Setelah dilakukan perhitungan dampak kapitalisasi sewa pada rasio keuangan dan elemen laporan keuangan lainnya, maka tahap selanjutnya yaitu melakukan analisis data:

a. Melakukan perbandingan dan analisis pada laporan keuangan khususnya laporan posisi keuangan antara sebelum dan setelah dilakukan kapitalisasi sewa operasi

b. Melakukan perbandingan dan analisis rasio keuangan, sebelum dan setelah dilakukan kapitalisasi sewa.

\section{HASIL PENELITIAN DAN PEMBAHASAN}

\section{A. Uji Statistik Deskriptif}

Tabel 1. Hasil Uji Statistik Deskriptif Laporan Posisi Keuangan

\begin{tabular}{|c|c|c|c|c|c|c|}
\hline Sether. & Ninimum & Nlaimum & Nedian & \multicolumn{2}{|c|}{ Stid Deviation } & Nean \\
\hline \multirow{12}{*}{ Total } & Labilo Pre & 53211965387.00 & 150154.57000000 .00 & 476022438100000000 & 34075090998379.7100 & 194015644419417.1700 \\
\hline & labily Pns & 53948640216.59 & 15653180302050011.00 & 50198565578228.1700 & 35528044707840.63000 & 20339753279861802030 \\
\hline & URL & 737740829.59 & 159146004091937.50 & 1002256804421.3500 & 25320366540988.38070 & 8502035800200.8807 \\
\hline & 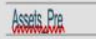 & 367894669331.00 & 22121200000000000.00 & 0271858000000.0000 & 5268200779420287000 & 310609150110226520 \\
\hline & Anesta Past & 30741420445330 & 231828561724150.00 & 677337238400552500 & 54051100026848.8700 & 3179657656020297.7100 \\
\hline & URA & 627370154,30 & 13533749942750.00 & 920442750060.4024 & 2154080025800.36000 & 736061550477.0552 \\
\hline & 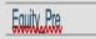 & .1355001127272891.00 & 11730300000000000 & 2409242427397.000 & 20244982022988.2400 & 112420062303059.3300 \\
\hline & Eaily Poss & .133025184840151 .40 & 115890002389180200 & 244090365997999900 & 229380001231105.0300 & 11114603926565.4900 \\
\hline & Deresese Eoudy & .2B8C6373499187.50 & .110370675 .20 & .106551307755 .5002 & 3786585236080.02330 & .128642309793 .8340 \\
\hline & UR Perpertace & .10 & 78.30 & 1.8779 & 14.25964 & 8.5068 \\
\hline & RA Persentiese & .66 & 24.06 & .0045 & 5.72128 & 36006 \\
\hline & Enity Peseriese & .26 .06 & .13 & .4036 & 4.39152 & .20330 \\
\hline
\end{tabular}

Hasil statistic deskriptif menunjukkan bahwa rata-rata jumlah sewa yang tidak dilaporkan oleh perusahaan (Unrecorded Lease Liability/URL) setelah terjadi kapitalisasi sewa adalah sebesar Rp 859.230.869.201, dimana persentase ratarata dari total liabilitas yang akan diungkapkan dalan liabilitas pada laporan posisi keuangan dalah $4,41 \%$, Jumlah terendah Liabilitas baik sebelum dan setelah kapitalisasi berasal dari sektor Perdagangan, Jasa dan Investasi dan nilai tertinggi liabilitas baik sebelum dan setelah adanya kapitalisasi berasal dari perusahaan keuangan. Dan yang Jumlah liabilitas mengalami peningkatan setelah terjadinya kapitalisasi sewa operasi, ratarata perusahaan mengalami peningkatan sebesar Rp 19.480.549.419.417 menjadi Rp 20.339.753.279.618.

Setelah dampak kapitalisasi sewa terhadap liabilitas diketahuim maka perlu dilakukan perhitungan atas asset sewa terhadap sewa yang tidak tercatat (Unrecorded lease assets/URA). Berdasarkan penelitian yang dilakukan oleh Bennet,et en, 2003, masa sewa diasumsikan memiliki nilai maksimum 10 tahun, dengan nilai bunga $10 \%$ dan $50 \%$ dari total masa sewa pada saat akan 
mengalami kadaluwarsa, sehingga rasio asset terhadap liabilitas memiliki nilai persentase sebesar $81 \%$. Pada awal sewa Unrecorde Lease Liability memiliki nilai yang sama dengan nilai dengan Unrecorded lease asset. Hanya saja nilai sewa akan mengalami pernurunan pada tingkat yang lebih cepat dibandingkan dengan nilai liabilitas sewa, hal tersebut dikarenakan adanya pembayaran awal sewa yang digunakan untuk pembayaran dari beban Bunga dibansingkan penggunaan untuk pembayaran bunga atas pinjaman pokok. Sedangkan berbanding terbalik dengan asset sewa yang mengalami penurunan karena adanya beban depresiasi yang ditanggung perusahaan setelah terjadinya kapitalisasi sewa. Setelah diketahui dari tabel data deskriptif, rata-rata jumalh asset hak guna yang tidak tersaji pada laporan posisi keuangan adalah sebesar $\mathrm{Rp}$ 730.661.550.407 atau setara dengan nilai $2,35 \%$ dari rata-rata total asset yang dilaporkan oleh perusahaan. Nilai Aset sewa yang tidak tercatat terletak pada perusahaan pada sektor dagang, jasa dan investasi. Sedangkan nilai tertinggi berasal dari perusahaan Infrastuktur, Utilitas dan Transportasi.

Dampak dari kapitalisasi sewa operasi juga memiliki dampak pada ekuitas dalam penyajian laporan posisi keuangan. Besarnya perubahan ekuitas didapat dengan cara menghitung selisih antara Unrecorded lease asset dan unrecorded lease liability, dan dilakukan penyesuaian dengan tari pajak yang berlau di Indonesia. Berdasarkan data statistic menunjukkan setelah adanya kapitalisasi sewa, maka rata-rata total ekuitas mengalami penurunan dengan jumalah $\mathrm{Rp}$ 128.542.309.794 atau setara dengan $1,14 \%$ dari total rata-rata ekuitas yang dilaporkan perusahaan sebelum terjadinya kapitalisasi sewa. Penurunan Ekuitas terkecil berasl dari perusahaan sektor Perdagangan, Jasa dan Investasi dan perusahaan yang mengalami penurunan ekuitas terbesar adalah perusahaan infrastuktur, utilitas dan transportasi.

\section{Tabel 2. Hasil Uji Statistik Deskriptif Rasio Keuangan}

\begin{tabular}{|c|c|c|c|c|c|}
\hline & Minimum & Maximum & Median & Std. Deviation & Mean \\
\hline DAR Pre & .10 & 4.90 & .5567 & .77846 & .6914 \\
\hline DAR Post. & .11 & 4.88 & .5617 & .77119 & .7108 \\
\hline DER Pre & -1.26 & 14.68 & 1.2233 & 2.62659 & 2.0241 \\
\hline DER Plost & -1.26 & 14.96 & 1.2319 & 2.94686 & 2.2584 \\
\hline ROA Pre & -20 & .47 & .0410 & .10943 & .0535 \\
\hline RQA Post. & -20 & .46 & .0366 & .10755 & .0471 \\
\hline ROE Pre & -.78 & 1.20 & .0928 & .26671 & .1006 \\
\hline RQE Elost & -1.17 & 1.20 & .0901 & .30246 & .0758 \\
\hline DIFFERENCE_DAR & -.02 & .16 & .0052 & .03113 & .0194 \\
\hline DIFFERENCE DER & .00 & 5.22 & .0346 & .72356 & .2342 \\
\hline DIFFERENCE ROA & -.04 & .00 & -.0015 & .01010 & -.0064 \\
\hline DIFFERENCE ROE & -.41 & .00 & -0037 & .07053 & -.0248 \\
\hline Changes DAR & -.44 & 44.50 & .9328 & 7.89729 & 4.3966 \\
\hline Changes.DER & .08 & 90.38 & 2.3037 & 18.88904 & 11.0732 \\
\hline Changess. BOA & -141.08 & 205.25 & -2.0323 & 43.82921 & -9.5025 \\
\hline Changes. RQE & -150.25 & 392.10 & -1.5932 & 61.96809 & -3.1219 \\
\hline
\end{tabular}

Dampak Kapitalisasi sewa operasi tidak hanya memiliki pengaruh dalam elemen laporan keuangan pada sisi Aset, Liabilitas dan Ekuitas. Lebih lanjut, dampak tersebut juga memiliki pengaruh terhadap kinerja perusahaan yang dapat ditunjukkan dengan adanya perubahan perhitungan dari rasio keuangan. Dalam penelitian ini rasio keuangan yang digunakan adal rasio Solcvabilitas di proksikan dengan Debt to Assets Ratio (DAR) dan Debt to Equity Ratio (DER). Rasio Profitabilitas diproksikan dengan Return on Asset dan Return on Equity $(R O E)$. Dengan adanya kapitalisasi sewa rata-rata untuk nilai DAR mengalami peningkatan dari nilai 0,6914 mengjadi 0,7108 setara dengan adanya peningkatan sebesar 2,81\% dengan nilai standar deviasi diatas nilai Mean menunjukkan bahwa nilai DAR heterogen dengan tingkat penyimpangan yang cukup tinggi. Rasio hutang terhadap ekuitas dapat ditunjukkan dengan nilai DER. Rata-rata nilai DER menunjukkan kenaikan dengan nilai 2,0241 menjadi 2,2584 atau setara dengan adanya peningkatan sebesar 11,57\%. Tetapi hal tersebut berbanding terbalik dengan nilai ROA yang mengalami penuruan dari sebelumnya $0, .0535$ menjadi 0,0471 atau setara dengan peningkatan persentase sebesar $-1,32 \%$. Dan sejalan 
dengan penurunan dari nulai ROA dimana rata-rata perusahaan mengalami penurunan sebesar $-24,69 \%$ dari nilai 0,1006 menjadi 0,0758. Dari standar deviasa yang ditunjukkan dimalah nilainya lebih besar dari nilai rata-ratanya maka data sampel dalam penelitian ini memiliki sifat yaan heterogen dengan nilai penyimpangan yang cukup tinggi.

\section{B. Uji Hipotesis.}

Analisis perbandingan antar sector menggunakan anova karena sector lebih dari 2 jenis, jika hanya ada 2 sektor maka analisis yang digunakan adalah independent $t$ test.

\subsection{Kapitalisasi Sewa Operas dan Laporan Posisi Keuangan}

Berikut ini adalah pengkodean sector:

\begin{tabular}{|c|c|}
\hline Kode & Sektor \\
\hline 1 & Basic Industry and Chemicals \\
\hline 2 & Consumer Goods Industry \\
\hline 3 & Finance \\
\hline 4 & $\begin{array}{lll}\text { Infrastructure, } & \text { Utilities } & \text { and } \\
\text { Transportation } & & \end{array}$ \\
\hline 5 & Mining \\
\hline 6 & Miscellaneous Industry \\
\hline 7 & Trade, Service, and Investment \\
\hline
\end{tabular}

Tabel 3. One-way Anova: Liability_Pre, Liability_Post Versus Sektor

\begin{tabular}{|c|c|c|c|c|c|c|}
\hline \multirow{2}{*}{$\begin{array}{l}\text { Sek } \\
\text { tor }\end{array}$} & Liability & \multirow{2}{*}{$\begin{array}{l}\text { P Pre } \\
\text { Std. } \\
\text { Dev. }\end{array}$} & \multirow{2}{*}{$\begin{array}{l}\text { Liability } \\
\text { Mean }\end{array}$} & \multirow{2}{*}{$\begin{array}{c}\text { y Post } \\
\text { Std. } \\
\text { Dev. }\end{array}$} & \multirow{2}{*}{$\begin{array}{l}\mathrm{P} \\
\text { Val } \\
\text { ue } \\
\end{array}$} & \multirow{2}{*}{$\begin{array}{l}\text { Ketera } \\
\text { ngan }\end{array}$} \\
\hline & Mean & & & & & \\
\hline 1 & $\begin{array}{l}1.59260 \\
E+13\end{array}$ & $\begin{array}{l}2.03755 \\
E+13\end{array}$ & $\begin{array}{l}1.61158 \\
E+13\end{array}$ & $\begin{array}{l}2.04456 \\
E+13\end{array}$ & $\begin{array}{l}0.0 \\
01\end{array}$ & $\begin{array}{l}\text { Terdapat } \\
\text { perbedaa } \\
\text { n }\end{array}$ \\
\hline 2 & $\begin{array}{l}9.57533 \\
E+12\end{array}$ & $\begin{array}{l}2.49850 \\
\mathrm{E}+12\end{array}$ & $\begin{array}{l}9.80110 \\
E+12\end{array}$ & $\begin{array}{l}2.56479 \\
E+12\end{array}$ & $\begin{array}{l}0.0 \\
01\end{array}$ & $\begin{array}{l}\text { Terdapat } \\
\text { perbedaa } \\
\mathrm{n}\end{array}$ \\
\hline 3 & $\begin{array}{l}5.04655 \\
E+13\end{array}$ & $\begin{array}{l}6.64976 \\
\mathrm{E}+13\end{array}$ & $\begin{array}{l}5.05704 \\
E+13\end{array}$ & $\begin{array}{l}6.66191 \\
\mathrm{E}+13\end{array}$ & $\begin{array}{l}0.0 \\
01\end{array}$ & $\begin{array}{l}\text { Terdapat } \\
\text { perbedaa } \\
\mathrm{n}\end{array}$ \\
\hline 4 & $\begin{array}{l}5.90872 \\
E+13\end{array}$ & $\begin{array}{l}3.52633 \\
E+13\end{array}$ & $\begin{array}{l}6.61284 \\
E+13\end{array}$ & $\begin{array}{l}4.12832 \\
\mathrm{E}+13\end{array}$ & $\begin{array}{l}0.0 \\
0.1\end{array}$ & $\begin{array}{l}\text { Terdapat } \\
\text { perbedaa } \\
\mathrm{n}\end{array}$ \\
\hline 5 & $\begin{array}{l}1.41751 \\
E+13\end{array}$ & $\begin{array}{l}1.19741 \\
\mathrm{E}+13\end{array}$ & $\begin{array}{l}1.46451 \\
E+13\end{array}$ & $\begin{array}{l}1.18134 \\
E+13\end{array}$ & $\begin{array}{l}0.0 \\
01\end{array}$ & $\begin{array}{l}\text { Terdapat } \\
\text { perbedaa } \\
\mathrm{n}\end{array}$ \\
\hline 6 & $\begin{array}{l}1.00294 \\
E+13\end{array}$ & $\begin{array}{l}6.16084 \\
E+12\end{array}$ & $\begin{array}{l}1.01573 \\
E+13\end{array}$ & $\begin{array}{l}6.04680 \\
E+12\end{array}$ & $\begin{array}{l}0.0 \\
01\end{array}$ & $\begin{array}{l}\text { Terdapat } \\
\text { perbedaa } \\
\mathrm{n}\end{array}$ \\
\hline 7 & $\begin{array}{l}6.37932 \\
E+12\end{array}$ & $\begin{array}{l}1.42851 \\
\mathrm{E}+13\end{array}$ & $\begin{array}{l}6.84567 \\
E+12\end{array}$ & $\begin{array}{l}1.45446 \\
E+13\end{array}$ & $\begin{array}{l}0.0 \\
01\end{array}$ & $\begin{array}{l}\text { Terdapat } \\
\text { perbedaa } \\
\mathrm{n}\end{array}$ \\
\hline
\end{tabular}

Berdasarkan hasil uji Annova menunjukkan nilai $\mathrm{P}$ Value adalah sebesar 0,001 atau kurang dari $<0,05$, maka dpat disimpulkan terdapat perbedaan bahwa akibat adanya kapitalisasi sewa berdampak pada adanya perbedaan nilai liabilitas Post dan Pre. Nilai mean tertinggi dari selisih antara nilai Liablitas pre dan post pada saat terjadinya kapitalisasi adalah pada perusahaan Infrasturcture, Utilitas dan Transportasi. Dimana nilai selisih tersebut adalah berkisar Rp 7.041.252.086.075 atau setara dengan nilai $11,92 \%$ dampak tersebut. Tingginya nilai dari Liabilitas disebabkan perusahaan sektor infrasture, Utilitas dan Transportasi memiliki beberapa jenis komiten sewa operasi salah satu contohnya adalah sewa jaringan, sewa peralatan telekomunikasi dan sewa tanah dan bangunan yang ada pada PT Telekomunikasi Indonesia Tbk. Hasil Penelitian sejalan dengan penelitian yang dilakukan oleh Duke, et al (2009), Öztürk \& Serçemel (2016), Wong \& Joshi (2015)dimana penelitian tersebut memberikan kesimpulan bahwa dampak dari kapitalisasi akan memberikan kenaikan nilai pada liabilitas yang ditimbulkan. Dari liabilitas sewa perusahaan.

Tabel 4. One-way Anova: Asset_Pre, Asset_Post Versus Sektor

\begin{tabular}{|c|c|c|c|c|c|c|}
\hline \multirow{2}{*}{$\begin{array}{l}\text { Sek } \\
\text { tor }\end{array}$} & \multicolumn{2}{|c|}{ Asset Pre } & \multicolumn{2}{|c|}{ Asset Post } & \multirow[t]{2}{*}{$\begin{array}{l}\text { P } \\
\text { Val } \\
\text { ue }\end{array}$} & \multirow[t]{2}{*}{$\begin{array}{l}\text { Ketera } \\
\text { ngan }\end{array}$} \\
\hline & Mean & $\begin{array}{l}\text { Std. } \\
\text { Dev. }\end{array}$ & Mean & $\begin{array}{l}\text { Std. } \\
\text { Dev. }\end{array}$ & & \\
\hline 1 & $\begin{array}{l}3.42673 \\
E+13\end{array}$ & $\begin{array}{l}3.77369 \\
E+13\end{array}$ & $\begin{array}{l}3.44287 \\
E+13\end{array}$ & $\begin{array}{l}3.78509 \\
E+13\end{array}$ & $\begin{array}{l}0.0 \\
00\end{array}$ & $\begin{array}{l}\text { Terdapat } \\
\text { perbedaa } \\
\text { n }\end{array}$ \\
\hline 2 & $\begin{array}{l}2.45013 \\
\mathrm{E}+13\end{array}$ & $\begin{array}{l}1.48558 \\
E+13\end{array}$ & $\begin{array}{l}2.46933 \\
E+13\end{array}$ & $\begin{array}{l}1.49466 \\
E+13\end{array}$ & $\begin{array}{l}0.0 \\
00\end{array}$ & $\begin{array}{l}\text { Terdapat } \\
\text { perbedaa } \\
\mathrm{n}\end{array}$ \\
\hline 3 & $\begin{array}{l}6.05654 \\
E+13\end{array}$ & $\begin{array}{l}7.89889 \\
E+13\end{array}$ & $\begin{array}{l}6.06545 \\
E+13\end{array}$ & $\begin{array}{l}7.90937 \\
E+13\end{array}$ & $\begin{array}{l}0.0 \\
00\end{array}$ & $\begin{array}{l}\text { Terdapat } \\
\text { perbedaa } \\
\mathrm{n}\end{array}$ \\
\hline 4 & $\begin{array}{l}1.20177 \\
\mathrm{E}+14\end{array}$ & $\begin{array}{l}8.56087 \\
E+13\end{array}$ & $\begin{array}{l}1.26164 \\
\mathrm{E}+14\end{array}$ & $\begin{array}{l}9.11430 \\
\mathrm{E}+13\end{array}$ & $\begin{array}{l}0.0 \\
00\end{array}$ & $\begin{array}{l}\text { Terdapat } \\
\text { perbedaa } \\
\mathrm{n}\end{array}$ \\
\hline 5 & $\begin{array}{l}2.07163 \\
E+13\end{array}$ & $\begin{array}{l}1.68052 \\
\mathrm{E}+13\end{array}$ & $\begin{array}{l}2.11160 \\
\mathrm{E}+13\end{array}$ & $\begin{array}{l}1.65955 \\
E+13\end{array}$ & $\begin{array}{l}0.0 \\
00\end{array}$ & $\begin{array}{l}\text { Terdapat } \\
\text { perbedaa } \\
\mathrm{n}\end{array}$ \\
\hline 6 & $\begin{array}{l}7.27966 \\
E+12\end{array}$ & $\begin{array}{l}3.66040 \\
E+12\end{array}$ & $\begin{array}{l}7.38836 \\
E+12\end{array}$ & $\begin{array}{l}3.72004 \\
E+12\end{array}$ & $\begin{array}{l}0.0 \\
00\end{array}$ & $\begin{array}{l}\text { Terdapat } \\
\text { perbedaa } \\
\mathrm{n}\end{array}$ \\
\hline 7 & $\begin{array}{l}61.2381 \\
8 \mathrm{E}+13\end{array}$ & $\begin{array}{l}2.95402 \\
E+13\end{array}$ & $\begin{array}{l}1.27783 \\
E+13\end{array}$ & $\begin{array}{l}2.97270 \\
E+13\end{array}$ & $\begin{array}{l}0.0 \\
00\end{array}$ & $\begin{array}{l}\text { Terdapat } \\
\text { perbedaa } \\
\mathrm{n}\end{array}$ \\
\hline
\end{tabular}

Berdasarkan hasil uji Annova menunjukkan nilai $\mathrm{P}$ Value adalah sebesar 
0,000 atau kurang dari $<0,05$, maka dapat disimpulkan terdapat perbedaan bahwa akibat adanya kapitalisasi sewa berdampak pada adanya perbedaan nilai Asset Post dan Pre. Nilai mean tertinggi dari selisih antara nilai Asset pre dan post pada saat terjadinya kapitalisasi adalah pada perusahaan Infrasturcture, Utilitas dan Transportasi. Perusahaan pada sektor tersebut memiliki banyak komitmen sewa opearasi di masa depan dimana komitmen tersebut memiliki perjanjian sewa yang tidak dapat dibatalkan. Dampak kapitalisasi berakibat munculnya asset lease yang harus diindentifikasikan pada laporan posisi keuangan yang dikategorikan sebagai asset tetap yang dimiliki dalam jangka Panjang. Hasil penelitian ini sejalan dengan penelitia yang dilakukan oleh Beattie et al, 1998, Duke et al, 2009, Wong \&Joshi, 2015

Tabel 5. One-way Anova: Ekuitas_Pre, Ekuitas_Post Versus Sektor

\begin{tabular}{|c|c|c|c|c|c|c|}
\hline \multirow{2}{*}{$\begin{array}{l}\text { Sek } \\
\text { tor }\end{array}$} & \multicolumn{2}{|c|}{ Equity Pre } & \multicolumn{2}{|c|}{ Equity Post } & \multirow[t]{2}{*}{$\begin{array}{l}\text { P } \\
\text { Val } \\
\text { ue }\end{array}$} & \multirow[t]{2}{*}{$\begin{array}{l}\text { Ketera } \\
\text { ngan }\end{array}$} \\
\hline & Mean & $\begin{array}{l}\text { Std. } \\
\text { Dev. }\end{array}$ & Mean & $\begin{array}{l}\text { Std. } \\
\text { Dev. }\end{array}$ & & \\
\hline 1 & $\begin{array}{l}1.83413 \\
E+13\end{array}$ & $\begin{array}{l}1.84226 \\
E+13\end{array}$ & $\begin{array}{l}1.83129 \\
E+13\end{array}$ & $\begin{array}{l}1.83930 \\
\mathrm{E}+13\end{array}$ & $\begin{array}{l}0.0 \\
00^{\circ}\end{array}$ & $\begin{array}{l}\text { Terdapat } \\
\text { perbedaa } \\
\mathrm{n}\end{array}$ \\
\hline 2 & $\begin{array}{l}1.49260 \\
E+13\end{array}$ & $\begin{array}{l}1.36268 \\
E+13\end{array}$ & $\begin{array}{l}1.48922 \\
E+13\end{array}$ & $\begin{array}{l}1.36112 \\
\mathrm{E}+13\end{array}$ & $\begin{array}{l}0.0 \\
00\end{array}$ & $\begin{array}{l}\text { Terdapat } \\
\text { perbedaa } \\
\mathrm{n}\end{array}$ \\
\hline 3 & $\begin{array}{l}9.98166 \\
E+12\end{array}$ & $\begin{array}{l}1.25157 \\
E+13\end{array}$ & $\begin{array}{l}9.96598 \\
E+12\end{array}$ & $\begin{array}{l}1.24963 \\
E+13\end{array}$ & $\begin{array}{l}0.0 \\
00^{\circ}\end{array}$ & $\begin{array}{l}\text { Terdapat } \\
\text { perbedaa } \\
n\end{array}$ \\
\hline 4 & $\begin{array}{l}5.68309 \\
E+13\end{array}$ & $\begin{array}{l}5.52454 \\
\mathrm{E}+13\end{array}$ & $\begin{array}{l}5.57774 \\
\mathrm{E}+13\end{array}$ & $\begin{array}{l}5.42627 \\
\mathrm{E}+13\end{array}$ & $\begin{array}{l}0.0 \\
00\end{array}$ & $\begin{array}{l}\text { Terdapat } \\
\text { perbedaa } \\
\mathrm{n}\end{array}$ \\
\hline 5 & $\begin{array}{l}6.54120 \\
E+12\end{array}$ & $\begin{array}{l}5.47754 \\
\mathrm{E}+12\end{array}$ & $\begin{array}{l}6.47088 \\
E+12\end{array}$ & $\begin{array}{l}5.53748 \\
\mathrm{E}+12\end{array}$ & $\begin{array}{l}0.0 \\
00\end{array}$ & $\begin{array}{l}\text { Terdapat } \\
\text { perbedaa } \\
\text { n }\end{array}$ \\
\hline 6 & $\begin{array}{l}- \\
2.74978 \\
E+12\end{array}$ & $\begin{array}{l}9.61432 \\
\mathrm{E}+12\end{array}$ & $\begin{array}{l}-\overline{2} \\
2.76890 \\
E+12\end{array}$ & $\begin{array}{l}9.59945 \\
\mathrm{E}+12\end{array}$ & $\begin{array}{l}0.0 \\
0.0\end{array}$ & $\begin{array}{l}\text { Terdapat } \\
\text { perbedaa } \\
\text { n }\end{array}$ \\
\hline 7 & $\begin{array}{l}6.00245 \\
E+12\end{array}$ & $\begin{array}{l}1.53715 \\
\mathrm{E}+13\end{array}$ & $\begin{array}{l}5.93268 \\
E+12\end{array}$ & $\begin{array}{l}1.53445 \\
E+13\end{array}$ & $\begin{array}{l}0.0 \\
00^{\circ}\end{array}$ & $\begin{array}{l}\text { Terdapat } \\
\text { perbedaa }\end{array}$ \\
\hline
\end{tabular}

Berdasarkan hasil uji Annova menunjukkan nilai $\mathrm{P}$ Value adalah sebesar 0,000 atau kurang dari <0,05, maka dapat disimpulkan terdapat perbedaan bahwa akibat adanya kapitalisasi sewa berdampak pada adanya perbedaan nilai Ekuitas Post dan Pre. Setelah adanya kapitalisasi sewa berdampak pada peningkatan beban yang harus diakui dan ditanggung oleh perusahaan. Adanya peningkatan beban tersebut berbanding terbalik dengan penurunan nilai Net Income (Laba bersih).
PSAK 73 dengan aturan yang mensyaratkan perusahaan mengadopsi metode tunggal, tidak hanya memiliki dampak pada akun Aset dan Liabilitas aja. Namun, kapitalisasi sewa operasi juga memiliki dampak perbedaan terhadap penurunan ekuitas. Berdasarkan tabel 5 diatas, menunjukkan bahwa nilai selisih rata-rata tertinggi antara Equitas sebelum kapitalisasi dan Ekuita setelah kapitalisasi terletak pada perusahaan Sektor Infrasktuktur, Utilitas dan Transportasi dan diikuti oleh sektro perdagangan, jasa dan investasi.

Hasil penelitian mengenai adanya perbedaan antara Ekuitas sebelum dan Ekuitas sesudah adanya perubahaan dampak dari kapitalisasi sejalan dengan penelitian yang dilakukan oleh Wong *Joshi (2015), dan Duke et al (2009).

\subsection{Kapitalisasi Sewa Operasi dan Rasio Keuangan}

\section{Paired T-Test and CI: DAR_Pre; DAR_Post}

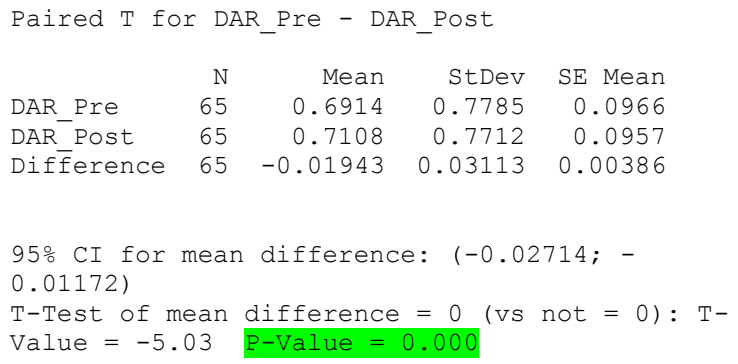

Terdapat berbedaan nilai rata-rata DAR antara pre dan post yang dibuktikan dengan nilai $\mathrm{p}$ value 0,000 (nilai $\mathrm{p}$ value < 0,05). Rata-rata DAR pada pre yaitu 0,6914 sedangkan pada post yaitu 0,7108 sehingga nilai DAR post lebih besar dari pre. Terjadinya Peningkatan nilai Debt to Asset Ratio (DAR), dikarenakan adanya peningkatan dari nilai liabilitas setelah adanya kapitalisasi sewa yang mempengaruhi jumlah tersebut pada laporan posisi keuangan. Pengingkatan asset hak guna, tidak sejalan dengan peningkatan dalam peningkatan liabilitas. Sehingga nilai DAR hanya mengalami 
peningkatan yang cukup rendah. Dari data statistic terlampir bahwa nilai paling berdampak pada rata-rata perubahan kapitalisasi sewa adalah sektor perdagangan, jasa dan investasi dan paling rendah rata-rata perubahaan tersebut adah perusahaan sektor aneka industry. Peningkatan tersebut mengindikasi adanya penurunan perusahaan dalam memberikan jaminan terhadap kewajibannya dalam penggunaan aseet yang dimiliki. Hasil penelitian ini didukung oleh penelitian yang digunakan Mashuri \& Ermaya (2021) dimana DAR mengalami peningkatan akibat penurunan kewajiban. Serta Wong and Joshi (2015), Benner et al (2003).

\section{Paired T-Test and CI: DER_Pre; DER_Post}

$\begin{array}{lrrrr}\text { Paired T for DER_Pre - DER_Post } \\ \\ \begin{array}{lrrrr} \\ \text { N }\end{array} & \text { Mean } & \text { StDev } & \text { SE Mean } \\ \text { DER_Pre } & 65 & 2.024 & 2.627 & 0.326 \\ \text { DER_Post } & 65 & 2.258 & 2.947 & 0.366 \\ \text { Difference } & 65 & -0.2342 & 0.7236 & 0.0897\end{array}$

95\% CI for mean difference: $(-0.4135 ;-0.0549)$ $\mathrm{T}$-Test of mean difference $=0(\mathrm{vs}$ not $=0): \mathrm{T}-$ Value $=-2$.

Terdapat berbedaan nilai rata-rata DER antara pre dan post yang dibuktikan dengan nilai $p$ value 0,011 (nilai $p$ value < 0,05 ). Rata-rata DER pada pre yaitu 2,024 sedangkan pada post yaitu 2,258 sehingga nilai DER post lebih besar dari pre. Adanya ppeningkatan dalam nilai DER disebabkan oleh nilai ekuitas yang menurun akibat dampaik dari kapitalisasi sewa. Sektor yang mengalami dampak terbesar terhadap nilai DAR adalah sektor pertambangan dan nilai terendah pada sektor keuangan. Kenaikan yang sangat signifikan pada perusahaan sektor tambang dikarenakan perusahaan memiliki alat-alat berat dalam penggunaan kegiatan operasioanl perusahaan, sehingga harga yang mahal dalam kepemilikan asset tetap tersedut menjadi salah satu faktor perusahaan untuk lebih memilih aktivitasi sewa operasi dalam pengadaan asset. Semakin tinggi nilai DER akan berdampak pada semakin tingginya resiko terjadinya likuiditas perusahaan, hal tersebut dikarenakan perusahaan tidak memiliki jaminan ekuitas untuk memenuhi kewajiban jangka Panjang yang ditimbulkan dari nilai unrecorded lease liabilitas (Mashuri dan Ermaya, 2021). Menurut penelitian Safitri, dkk (2018), peningkatan nilai DAR akibat dampak Kapitalisasi sewa tidak mengalami dampak yang signifikan, karena perusahaan tidak mengandalkan ekuitas dalam penjaminan hutangnya.

\section{Paired T-Test and CI: ROA_Pre; ROA_Post}

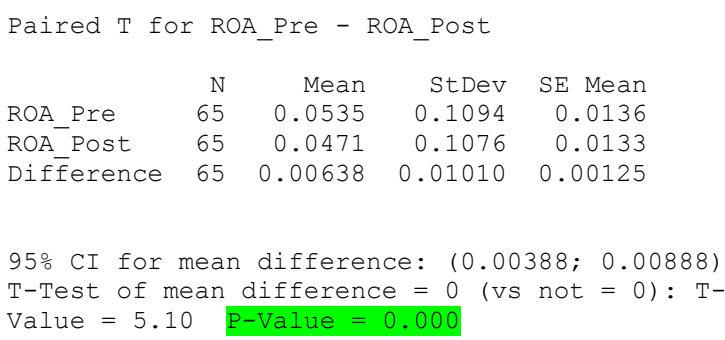

Terdapat berbedaan nilai rata-rata ROA antara pre dan post yang dibuktikan dengan nilai $\mathrm{p}$ value 0,000 (nilai $\mathrm{p}$ value $<$ 0,05). Rata-rata ROA pada pre yaitu 0,0535 sedangkan pada post yaitu 0,0471 sehingga nilai ROA post lebih kecil dari pre. Pernurunan dari nilai ROA dampak dari kapitalisas sewa disebabkan adanya peningkatan asset hak guna dan penurunan nilai income bersih perusaahan, sehingga berdampak pada penurunan rasio profitabilitas. Peningkatan hak sewa guna menimbulkan beban depresiasi dan beban Bunga liabilitas sewa, namun menghapuskan beban sewa operasi atas beban asset lease pada laporan laba rugi. Pengakuan beban yang lebih besar tersebut berdampak pada penurunan net income. Nilai ROA yang berdampak paling besar akibat kapitalisasi sewa adalah perusahaan yang berasal pada sektor Infrastruktur, Utilitas dan Transportasi dan terendah adalah persuahaan pada sekrot Industri Dasar dan Kimia. Penelitian ini sejalan dengan penelitian yang dilakukan oleh Nuryani, et al (2015), Wong and Joshi (2015), serta Bettie et al (1998), Mashuri dan Ermaya (2021). 
Paired T-Test and CI: ROE_Pre; ROE_Post

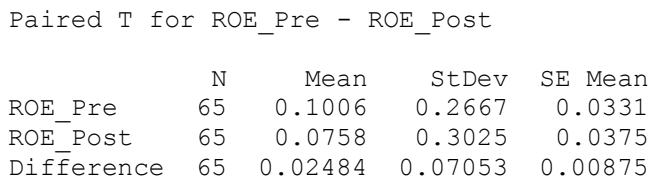

95\% CI for mean difference: (0.00736; 0.04232) $\mathrm{T}$-Test of mean difference $=0($ vs not $=0): \mathrm{T}-$ Value $=2.84$

Terdapat berbedaan nilai rata-rata ROE antara pre dan post yang dibuktikan dengan nilai $p$ value 0,006 (nilai $p$ value < 0,05). Rata-rata ROE pada pre yaitu 0,1006 sedangkan pada post yaitu 0,0758 sehingga nilai ROE post lebih kecil dari ROE pre. Dampak dari kapitalisasi sewa menyebabkan adanya pengakuan yang lebih besar, karena munculnya beban depreasisi serta beban bunga akibta pembayaran liabilitas sewa. Sehingga, berpengaruh pada nilai net income yang mengalami penurunan. Penurunan dari net income berdampak pula pada ekuitas pada perusahaan. Nilai Tertinggi dampak kapitaliasi pada ROE terletak pada perusahaan sektor Infrastruktur, Utilitas dan Transportasi dan terendah terdapat pada sektor perusahaan Industri Barang Konsumsi. Hasil penelitian tersebut sejalan dengan penelitian Wong and Joshi (2015), Beattie et al (1998). Serta Ozturk dan Secemelli (2016), tidak sejalan dengan penelitian yang dilakukan oleh Nuryani, et al (2015).

\section{Kesimpulan dan Saran Simpulan}

Disahkannya PSAK 73 yang efektif pada tanggal 01 Januari 2020, menuntut perusahaan yang terdaftar di Bursa Efek Indonesia untuk mematuhi standar tersebut berdasarkan konvergensi IFRS 16. Essentialnya standar baru tersebut mengatur kegiatan sewa yang berlaku bagi pihak lessee. Dalam standar yang berlaku, model akuntasi tunggal diperkenalkan sebgai capital lease. Perubahan tersebut memiliki dampak adanya perubahan dalam struktur modal, jumlah angka pada laporan lab rugi dan laporan posisi keuangan serta rasio keuangan yang dapat menggambarkan kinerja perusahaan. Sehingga, dalam penelitian dilakukan untuk mengetahui apakah kapitalisasi sewa operasi memiliki dampak adanya perubahan dalam laporan keuangan. Berdasarkan uji Hipoteses yang dilakukan dengan menggunakan uji Paired $T$ Test dan Annova dapat diambil kesimpulan bahwa:

1. Kapitalisasi sewa operasi memiliki pengaruh signifikan terhadap unrecorded lease liability (URL). Perubahaan tersebut memiliki pengaruhnya terhadap pengakuan, pengukuran serta pengungkapan liabilitas sewa. Pengakuan tersebut dimunculkan akibat perubahan kebijakkan yang mewajibkan diterapkan kapitalisasi sewa yang sebelumnya diindentifikasikan dalam operating lease. Kapitalisasi sewa operasi juga memiliki pengaruh signifikan terhadap unrecorded lease assets (URA). Dalam laporan posisi keuangan, keberadaan kegiatan sewa operasi yang diindentifikasi akan berubah menjadi ditiadakan pada laporan laba rugi, dan muncul pada lapora posisi keuangan sebagai Lease Asset atau Asset lease. Hal tersebut akan berdampak pada perubahan total asset yang semakin meningkat. Lebih lanjut, berbanding terbalik dengan keberadan kapitalisasi sewa operasi pada ekuitas. Nilai ekuitas mengalami penurunan pada saat terjadi perubahaan kebijakan tunggal atas sewa. Dikarenakan beban atas depresiasi dan beban bunga atas liabilitas lease berdampak pada penuruan nilai net income pada laporan laba rugi kegiatan operasional perusahaan.

2. Kapitalisasi sewa juga memiliki dampak secara keseluruhan atas kinerja perusahaan dengan adanya perubahan 
rasio keuangan secara parsial yang menggunakan data laporan keuangan perusahaan dalam proksi pengukuran.

\section{Saran}

Berdasarkan penjelasan dan simpulan yang telah disampaikan, maka penelitian ini diharapkan dapat memberikan saran kepada beberapa pihak diantaranya adalah bagi praktisi akuntansi dan regulator dalam penyusunan rencana dan kebijakan dapat mempertimbangkan untuk mewajibkan perusahaan mengungkapkan nominal biaya atas alternative pinjaman yang dilakukan perusahaan dalam perolehan atas asset lease, serta melakukan pengungkapan portofoli sisa umur sewa sehingga infor-masi yang disajikan dapat mempengaruhi dalam pengambilan keputusan manajerial atas efesiensi asset lease tersebut.

Dan bagi peneliti selanjutnya, dapat melakukan pengembangan penelitian terkait kapitalisasi sewa operasi dan penerapan dari PSAK 73 atas sewa. Dengan cara menganalisa lebih lanjut pengungkapan sukarela dengan menggunakan pengukuran nilai sekarang atas komitmen sewa yang di sajikan perusahaan pada catatan atas laporan keuangan, sehingga dapat membantu perusahaan mengetahui informasi mengenai hutang yang bisa jadi menjadi salah satu faktor manajerial untuk menyembunyikan demi alasan pemberian kompensasi dan kinerja manajerial.

\section{DAFTAR PUSTAKA}

Ahalik. (2019). Perbandingan Standar Akuntansi Sewa PSAK 30 Sebelum dan Sesudah Adopsi IFRS serta PSAK 73. Perbandingan Standar Akuntansi Sewa PSAK 30 Sebelum Dan Sesudah Adopsi IFRS Serta PSAK 73, 11(1), 165-173. doi: 10.17509/jaset.v11i1.17612

Alabood, E., Abuaddous, M., \& Bataineh, H. (2019). The impact of IFRS 16 on airline companies: An exploratory study in the Middle East. 18(1), 112128.

doi:

10.1504/IJEBR.2019.100654

Beattie, V., Edwards, K., \& Goodacre, A. (1998). The impact of constructive operating lease capitalisation on key accounting ratios. Accounting and Business Research, 28(4), 233-254. doi:

10.1080/00014788.1998.9728913

Bennett, B. K., \& Bradbury, M. E. (2003). Capitalizing non-cancelable operating leases. Journal of International Financial Management and Accounting, 14(2), 101-114. doi: 10.1111/1467-646X.00091

Duke, J. C., Franz, D., \& Hsieh, S. J. (2012). Evaluating Constructive Lease Capitalization and OffBalance-Sheet Financing: An Instructional Case with FedEx and UPS. Accounting Perspectives, 11(1), 57-69. doi: 10.1111/j.19113838.2012.00031.x

Duke, J. C., Hsieh, S. J., \& Su, Y. (2009). Operating and synthetic leases: Exploiting financial benefits in the post-Enron era. Advances in Accounting, 25(1), 28-39. doi: 10.1016/j.adiac.2009.03.001

Ghozali, I. (2013). Aplikasi Analisis Multivariate dengan Program IBM SPSS 21 Update PLS Regresi. Semarang: Badan Penerbit Universitas Diponegoro.

Hery. (2016). Analisis Kinerja Manajemen. Jakarta: Grasindo.

Ikatan Akuntan Indonesia. (2020). Standar Akuntansi Keuangan. Jakarta: Salemba Empat.

Imhoff, E. A., Lipe, R., \& Wright, D. (1991). Operating leases: Impact of constructive capitalization. Accounting Horizons, 5(1), 51-63. https://doi.org/10.1016/j.sbspro.2015. 11.034

Kieso. (2014). Intermediate Accounting IFRS Edition 2nd ed. United States of America: John Wiley \& Sons, Inc.

Magli, F., Nobolo, A., \& Ogliari, M. 
(2018). The Effects on Financial Leverage and Performance: The IFRS 16. International Business Research, 11(8), 76. doi: 10.5539/ibr.v11n8p76

Martani, D., Siregar, S. V., Wardhani, R., \& Farahmita, A. (2016). Akuntansi Keuangan Menengah Berbasis PSAK. Jakarta: Salemba Empat.

Mashuri, A. A. S., \& Ermaya, H. N. L. (2021). Penerapan Standar Akuntansi PSAK 73 Leases Terhadap Kinerja Keuangan Perusahaan yang Terdaftar di Bursa Efek Indonesia. Jurnal MONEX, 10(1).

Nuryani, N., Heng, T. T., \& Juliesta, N. (2015). Capitalization of Operating Lease and Its Impact on Firm's Financial Ratios. Procedia - Social and Behavioral Sciences, 211(September), 268-276. doi: 10.1016/j.sbspro.2015.11.034

Öztürk, M., \& Serçemeli, M. (2016). Impact of New Standard "IFRS 16 Leases" on Statement of Financial Position and Key Ratios: A Case Study on an Airline Company in Turkey. Business and Economics Research Journal, 7(4), 143-143. doi: 10.20409/berj.2016422344

Putri, H. S., Kirana, D. J., \& Sari, R. H. D. P. (2018). Determinan Penerapan Revaluasi Aset Tetap. Konferensi Riset Nasional Ekonomi, Manajemen, Dan Akuntansi 1.

R.Scott, W. (2015). Financial Accounting Theory. Canada: Person Prentice.

Safitri, A., Lestari, U. P., \& Nurhayati, I. (2019). Analisis Dampak Penerapan PSAK 73 Atas Sewa Terhadap Kinerja Keuangan Pada Industri Manufaktur, Pertambangan dan Jasa yang Terdaftar di Bursa Efek Indonesia Tahun 2018. Prosiding Industrial Research Workshop and National Seminar, 10(1), 955-964.

Supardi. (2013). Aplikasi Statistika dalam Penelitian. Jakarta Selatan: Change Publication.

Septiana, A. (2019). Analisis Laporan
Media Publising.

Sutedi, A. (2012). Good Corporate Governance. Jakarta: Sinar Grafika.

Widyatuti, M. (2017). Analisa Kritis Laporan Keuangan. Surabaya: CV. Jakad Media Nusantara.

Wijaya, D. (2017). Manajemen Keuangan Konsep dan Penerapannya. Jakarta: PT Grasindo.

Wong, K., \& Joshi, M. (2015). The impact of lease capitalisation on financial statements and key ratios: Evidence from Australia. Australasian Accounting, Business and Finance Journal, 9(3), 27-44. doi: 10.14453/aabfj.v9i3.3

Keuangan. Pamengkasan: Duta 